\title{
A NEW WAY TO ELIMINATE THE ROOT ROT FUNGI IN GREEN FODDER UNDER THE HYDROPONIC CONDITIONS
}

\author{
$\underline{\text { AlAzab Alrefaey }}{ }^{1}$, A. M. Nofal ${ }^{2}$,Aida Allam ${ }^{3}$, Eman I. EL- Serag ${ }^{4}$. \\ 1-3. Natural Resources Evaluation Department, Environmental Studies and Research Institute, University of Sadat City. \\ 2. sustainable development Department, Environmental Studies and Research Institute, Sadat City University. \\ 4. Prof. Agronomy, Head of Plant production Department, Fac. Environ. Agric. Sci., Arish University.
}

\section{$\underline{\text { ABSTRACT }}$}

$\mathrm{T}$ his study was done to indicate the activity of secondary metabolites of cyanophyta algal extracts for Anabaena Azolla which live in Azolla plant in Egypt and to study the effective of secondary metabolites in An.Azolla extracts (cold water and methanol extracts) to inhibition species of fungi (Fusarium oxysporum, penicillium expansum, Aspergillus niger and candida albicans) also used of HPLC analysis to detected some of active secondary metabolites was done only for methanol extracts also to preliminary statements that used of two extracts of blue green alga Anabaena Azolla. The role of An.Azolla extracts to inhibition growth of these fungi was detected through measured diameter of inhibition zone diameters were, 16.58, 11.42, 11.0 \& $11.0 \mathrm{~mm}$ in case of Fusarium oxysporum, Penicillium expansum, Aspergillus niger and candida albicans respectively, but aqueous extract give inhibition zone were 18.15, 14.13, 14.0 \& $13.0 \mathrm{~mm}$ respectively. and the results showed these extracts had high correlation ratio and fungi shows high sensitivity to these extract. The mode of mechanism action to inhibition was on fungi cell wall by inhibition active enzymes, excelled treatment for cold water extract . The most important active compounds had been detected in HPLC were phenolic compounds and flavonoids compounds these all compounds detected specially in methanol extract of An.Azolla. The experiment has been conducted under temperature and artificial illumination at growth room of Soilless Culture Laboratory, Sadat city University, Egypt. The results showed that green fodder can be produced in 8 days using hydroponic technique. Trays treated with Azolla gave more green fresh yield (11.8 kg/tray) than untreated ones (7.2 kg/tray). Adding Azolla increased protein content and the percentages of $\mathrm{N}, \mathrm{P}, \mathrm{K}$ by $28.7 \%$ and $0.98,0.82,0.70 \%$, respectively, as compared to no addition of Azolla. Zero disease incidences were achieved with treated by Azolla as compared to $26.0 \%$ with those untreated by Azolla. It could be concluded from this study that adding Azolla to hydroponic barley forage production improved green forage yield and its chemical analysis and free from root rot fungi.

Keywords: Hydroponic barley, root rot fungi, Anabaena Azolla, inhibition growth, Secondary compounds, HPLC. Antifungal . Bioactivity. Extracts 


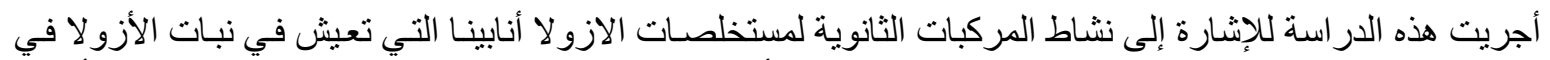

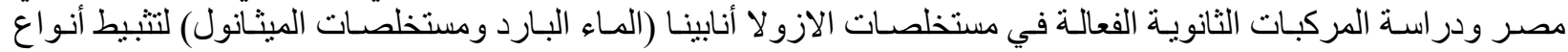

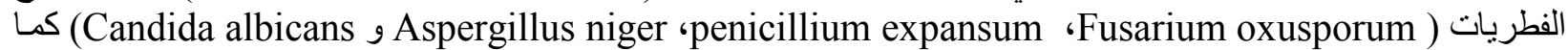
استخدم تحليل HPLC للكثف عن بعض المركبات الثانوية النشطة كانت فقط لمستخلصات الميثانول و أيضًا إلى مركبات أولية

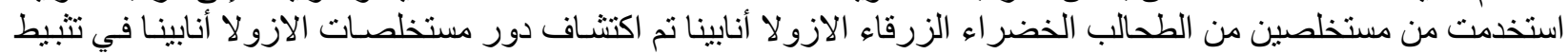

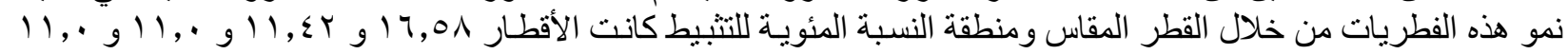

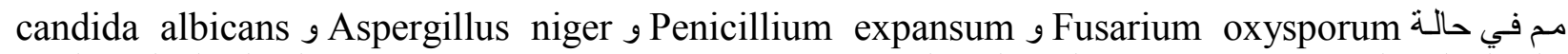

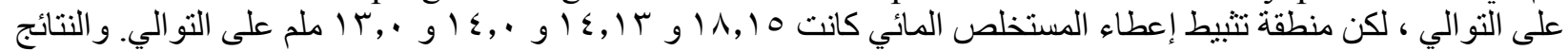

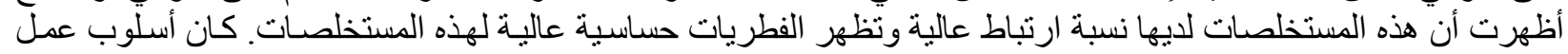

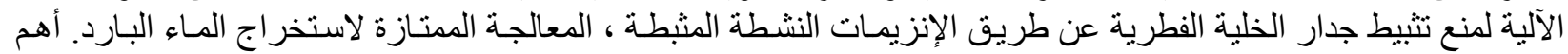

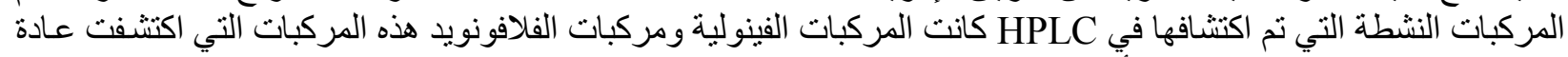
في مستخلص الميثانولَ من الازو لا أنابينا.

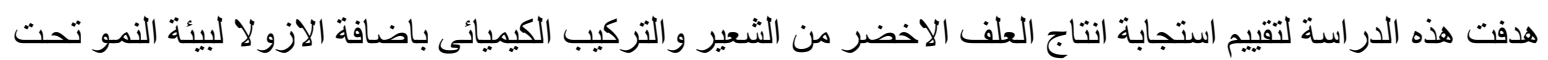

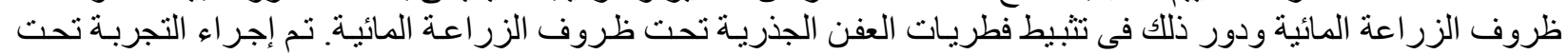

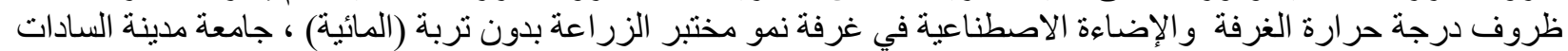

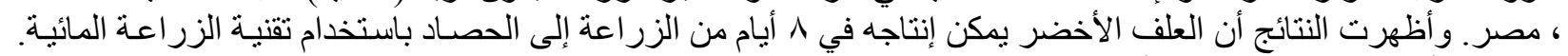

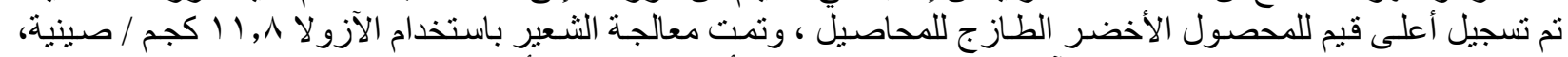

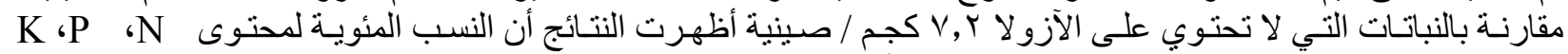

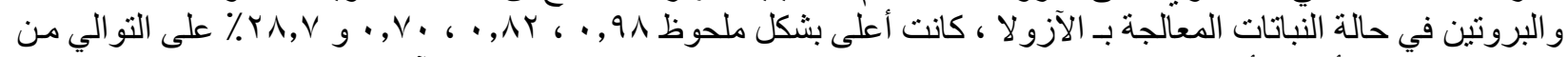

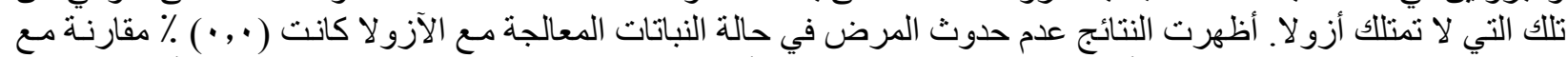

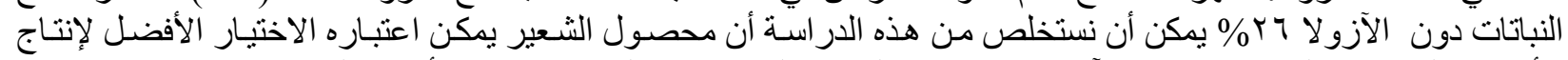
الأعلاف الخضر اء المائية باستخدام الآزو لا بها نسبة عالية من البروتين وخالية من فطريات ألغان أعفان الجذور.

\section{INTRODUCTION}

Anabaena Azolla is one of cyanophyta type which is contain of heterocyst and gas vacuole (Rippka, et al., 1979) Anabaena can produce toxins in fresh aquatic water ecology and the bloom of An.Azolla lead to produce alkaloids neurotoxins anatoxin (Sivonen, and Jones, 1999) show that Anabaena can produce three types of toxins like anatoxins(s) which is organophosphate toxins, carbmate toxins and saxitoxins ( $\mathrm{LD}_{50}$ is $10-30 \mathrm{mg} / \mathrm{kg}$ ) (WHO, 2003). Anabaena also produce microcystin-LR which is type of hepato toxins and there $\left(\mathrm{LD}_{50}\right.$ is $40-70$ $\mathrm{mg} / \mathrm{kg}$ ) and produce cylindrospermopsin which mechanism is to inhibition of Protein synthesis of fungi (Griffiths and Saker, 2003). Anabaena produce these toxins as secondary compounds that used to inhibition growth of pathogenic fungi and the unsaturated fatty acids consider important source to produce toxins because its contain of toxic chemical properties and these secondary compounds contracts with hormonal and toxically effects against microbes (Moe, 1997). This algae can produce lipopolysaccharides endotoxins inhibition of fungi (Blahova, et al., 2013) because of this algae can produce many types of toxins and for this reason we can used Anabaena extracts as antibiotics against Fusarium oxysporum and Penecillium expansum (Yousif, 2014). An.Azolla also used in biological control to inhibition of undesirable microbes because its contain many benefits with estats against fungi and this way is more safety for ecology by compare with synthesis fungal pesticides (Salman, 2015) .

Hydroponics is an advanced technology in agriculture. These techniques can meet the growing nutrients requirement for livestock feed with suitable prices, in addition to guarantee a constant production of high quantity of green forage throughout the year. Hydroponic fodder production is a technique of growing crops such as barley, in a hygienic environment free of chemicals, and artificial growth promoters (Jensen and Malter, 1995). Hydroponically fodder has a short growth period (around 7-10 days) and requires a small piece of land for production (Mooney, 2005). It has high feed quality that is rich with proteins, fibers, vitamins, and minerals 
(Bhise et al., 1988; Chung et al., 1989) with health beneficial effects on animals (Boue et al., 2003).

Azolla spp. are small free-floating aquatic pteridophytes, belonging to the family Azollaceae, with a worldwide distribution on tropical, subtropical and temperate regions. This fernis unique as it has an everlasting symbiosis with the nitrogen fixing cyanobacterium Anabaena Azolla inhabiting cavities in the Azolla dorsal lobes. This fern, although considered an invasive species, can be used as biofertilizer, in the phytoremediation of domestic and industrial wastewater and as animal or human food (Wagner 1997; Carrapiço 2010).

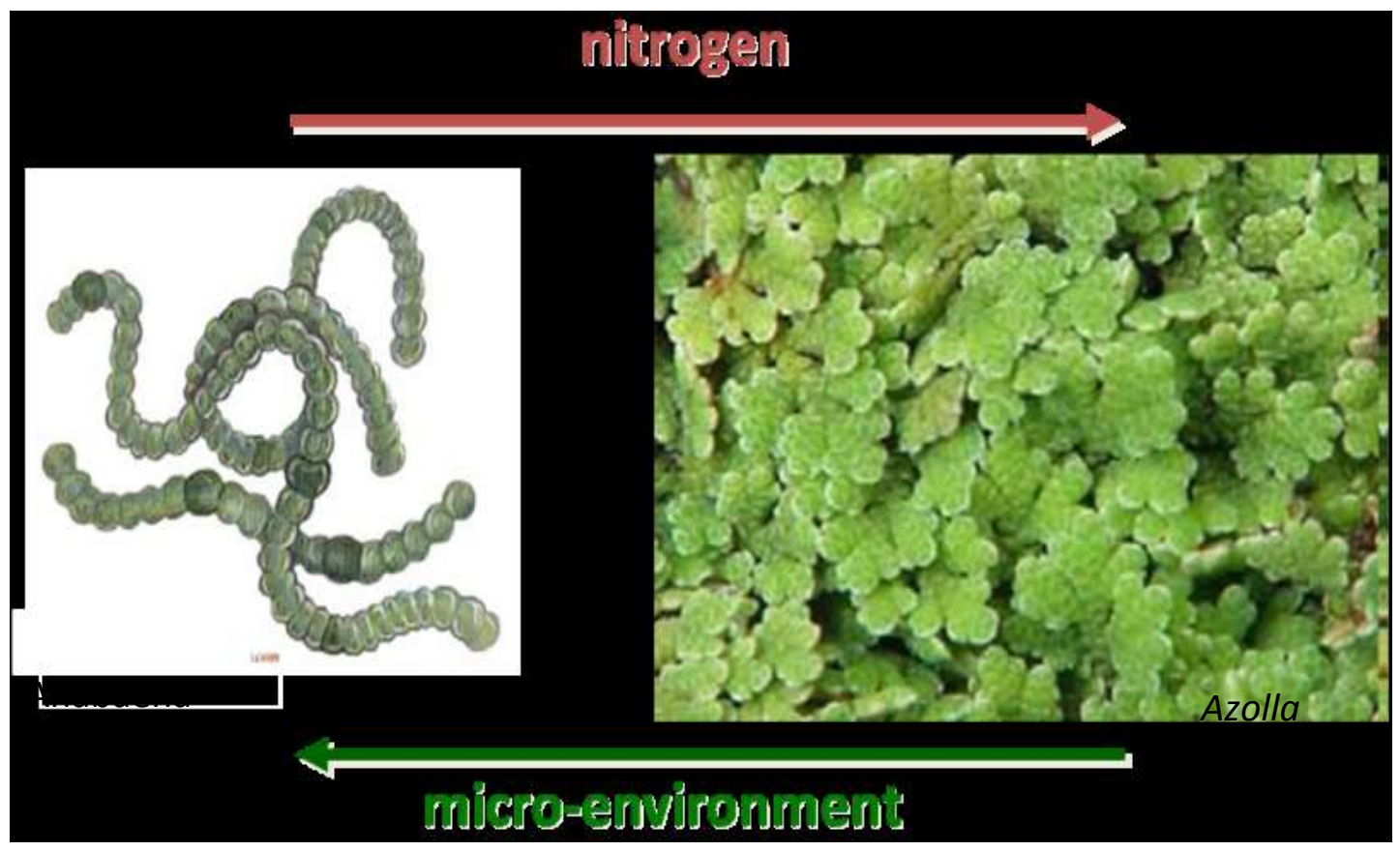

Fig. 1: Azolla-Anabaena system to fix atmospheric nitrogen

The aim of the present research was to evaluate the biological activities of organic and aqueous extracts from six Azolla species against root rot fungi.

\section{MATERIALS AND METHODS}

\section{A) VITRO EXPERIMENTS:}

\subsection{SAMPLE COLLECTION AND IDENTIFICATION:}

Azolla species were obtanined from Agriculture Research Center Gizza, Egypt and were cultured in Hoagland medium (H-40), $\mathrm{pH}$ 6.1-6.2, with controlled temperature, photoperiod and light intensity (Pereira and Carrapiço 2009). The collected biomass was washed in water, stored at $-80^{\circ} \mathrm{C}$, lyophilized and weighted.

\subsection{EXTRACTION OF AQUEOUS AND ORGANIC COMPOUNDS}

The lyophilized biomass of Azolla was ground in a mill and extracted twice with dichloromethane: methanol $(2: 1, \mathrm{v} / \mathrm{v})$ for $3 \mathrm{~h}$, vacuum filtered through paper filter (Whatmann $\mathrm{N}^{\circ}$ 1) and cheese cloth and evaporated until dryness in a rotary evaporator thus yielding the organic fraction which was weighted and stored at $-80^{\circ} \mathrm{C}$.

To obtain the aqueous fraction, the organic solvent extracted biomass was extracted twice with ultrapure water for $2 \mathrm{~h}$, sonicated with an ultrasound probe at $20 \mathrm{kHz}$ for $7 \mathrm{~min}$., filtered through a cheese cloth and paper filter (Whatmann $\mathrm{N}^{\circ} 1$ ), centrifuged at $4542 \mathrm{rpm}$ for $30 \mathrm{~min}$. at room temperature. The supernatant was frozen, lyophilized until dryness, weighted and stored at 
$-80{ }^{\circ} \mathrm{C}$. Prior to the bioassays, all extracts were resuspended in DMSO to obtain a stock concentration of $100 \mathrm{mg} / \mathrm{ml}$, except for the organic extract and stored at $-20{ }^{\circ} \mathrm{C}$.

\subsection{DETERMINATION OF ANTIMICROBIAL ACTIVITY}

The obtained extract was dissolved in Dimethyl sulfoxide (DMSO).. Both bacterial and fungi microbes were grown on nutrient agar medium. The fungal strain was on other hand grown on PDA medium. The culture of each microorganism was diluted by sterile distilled water to $10^{7}$ to $10^{8} \mathrm{CFU} / \mathrm{ml}$. The inoculated agar plates were incubated in the upright position for $24 \mathrm{hrs}$ (bacteria) at $37^{\circ} \mathrm{C}$ for bacteria and $48 \mathrm{~h}$ at $30^{\circ} \mathrm{C}$ for fungi and yeast. After incubation, the diameter of inhibition zones were measured against a wide range of test microorganisms comprising: Gram+ve bacteria; Staphylococcus aureus ATCC6538-P), Gram -ve bacteria Pseudomonas areuginosa ATCC 27853), yeasts (Candida albicansATCC10231 and the fungus Aspergillus niger NRRLA-326. All test microbes were obtained from the culture collection center, Microbial Chemistry Department, National Research Center, Egypt and isolates fusarium oxysporum, penicillium expansum obtained from plant pathology lab, faculty of agriculture Mansoura university.

\subsection{HPLC ANALYSIS:}

The chemical composition of Azolla extract were performed in International Research Center, Gizza, Egypt (central labs unit) for detected phenolic, flavonoids and other active componds.

\subsection{ULTRASTRUCTURE STUDIES:}

\section{Method of specimen preparation for transmission electron microscopy}

The method described here is an example for fixation, contrastation and embedding only . For optimal results especially the fixation needs to be adapted to the investigated tissue . It is of major importance that the fixing agent is able to completely. Penetrate the specimen as soon as possible. For this reason only very small pieces of tissue $\left(\sim 1 \mathrm{~mm}^{3}\right)$ should be fixed if no perfusion fixation (fixative is directly infused into a larger vessel of a deeply anaesthized animal) should be possible. The preparation should be quick enough, i.e. 5 minutes after tissue does no longer receive oxygen, and it began to show first signs of degeneration of ultra-structures. Perfusion or immersion fixation of the tissue using a modified Karnovsky (1965) solution : $2.5 \%$ buffered glutaraldehyde $+2 \%$ paraformaldehyde in $0.1 \mathrm{M}$ sodium phosphate buffer $\mathrm{pH} 7.4$ , leave tissue overnight at $4^{\circ} \mathrm{C}$, wash $3 \times 15$ minutes (min.) in $0.1 \mathrm{M}$ sodium phosphate buffer + $0.1 \mathrm{M}$ Sucrose, postfix $90 \mathrm{~min}$. in $2 \%$ sodium phosphate buffered osmium tetroxide $\mathrm{pH} 7.4$, wash $3 \times 15 \mathrm{~min}$ in $0.1 \mathrm{M}$ sodium p, after drying for $\sim 15 \mathrm{~min}$ sections may be investigated in a transmission electron microscope . Ultrathin sections were observed at $160 \mathrm{kV}$ using a JEOL JEM -2100 at EM Unit, Mansoura University, Egypt.

\section{B) VIVO EXPERIMENTS:}

This study was conducted under room temperature for all months of the year and artificial illumination at growth room of Soilless Culture Laboratory, Sadat city University, Egypt. A hydroponic system composed from metal frame was designed and assembled from local materials has been used in this study. 


\section{C) The Hydroponic System.}

The hydroponic system is composed of two cabinets (units) with metal frame and four shelves each with a length of $200 \mathrm{~cm}$, a width of $72 \mathrm{~cm}$, and a height of $240 \mathrm{~cm}$. Each unit of the system could carry 25 planting trays with capacity to produce approximately $80-100 \mathrm{~kg}$ green fodder per growth cycle ( 9 days), depending on crop variety and growth conditions (Al-Karaki and Al-Momani, 2010). The horizontal area occupied by each unit of the system was about $2 \mathrm{~m}^{2}$ including the pathways between neighboring units. However, the number of units of the hydroponic system can be increased and planting date scheduled for daily production of green fodder to meet the daily demand of animals in the farm. Polystyrene trays with a length of 70 $\mathrm{cm}$, a width of $30 \mathrm{~cm}$ and a depth of $58 \mathrm{~cm}$ were used for growing seeds to produce green fodder. These trays were obtained from the local market. The units of hydroponic system have been arranged in the growth room with artificial illumination. Under room temperature was used to control temperature inside the growth room. The relative humidity in the growth room ranged between 50 and $73 \%$.

\subsection{PLANT MATERIAL.}

Forage crop was evaluated in this study which was: barley (Hordeum vulgare L.), Seeds of this crop was obtained from the local market of Cairo city, Egypt. Seeds of the barley crop were subjected to a germination test to check for their viability before being used; the germination percent was $73 \%$.

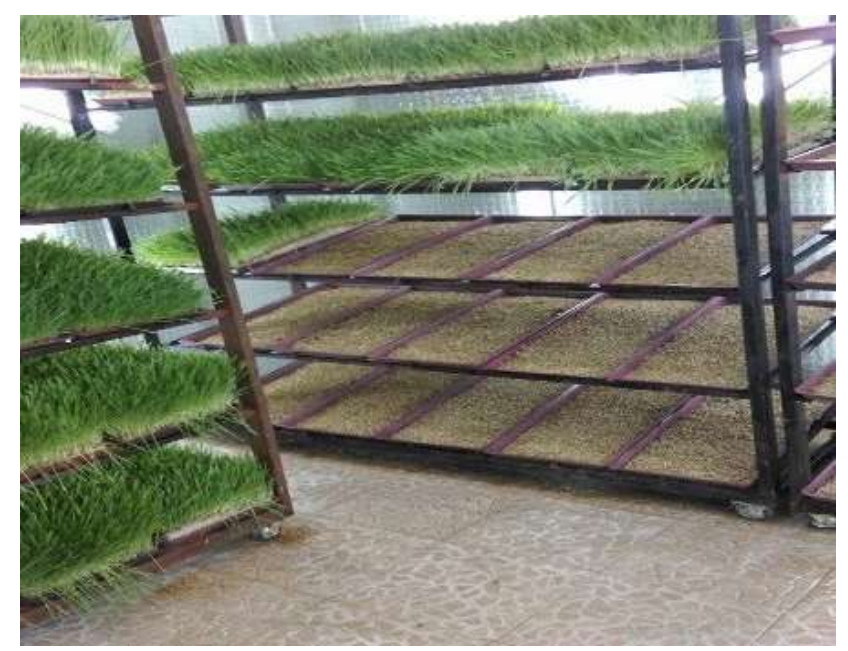

Fig. 2: The hydroponic system in which planting trays were stacked after seeding of barley crop.

\subsection{TREATMENT OF SEEDS BEFORE PLANTING.}

Seeds of barley were cleaned from debris and other foreign materials. Then seeds soaked in tap water overnight (about 12 hours) before planting.

\subsection{SEED PLANTING AND IRRIGATION.}

First treatment trays, soaked barley seeds germinated upon fresh Azolla which was as lower surface, but the second treatment trays (control) kept without Azolla. All trays were lined with plastic sheets and have holes at the bottom to allow drainage of excess water from irrigation. The seeding rates were about $450 \mathrm{~g} /$ tray. The trays were stacked on the shelves $(25$ trays/5 shelves) (Ghazi \& Al Hasim, 2012). Trays were irrigated manually with tap water twice a day (early in the morning and late in the afternoon) at a fixed rate of $500 \mathrm{ml} /$ tray. day which was enough to keep the seeds/seedlings moist Figure 3. 


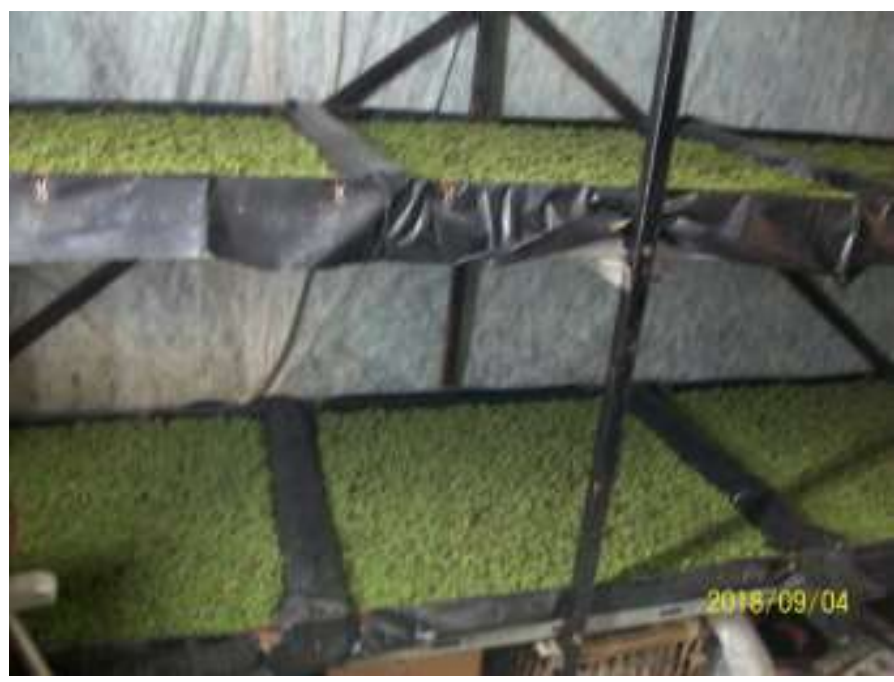

Fig. 3: Azolla culture spread at low surface

\section{FORAGE YIELD:}

The experiment was terminated after 8 days from seeding, where the fodder biomass was ready for harvest (Fig 4). At harvest time, the following data were recorded per tray. total fresh and dry fodder yields, seedling height, leaf colour, percentage of $\mathrm{N}, \mathrm{P}, \mathrm{K}$ and protein contant. Also the disease incidence (DI) $\frac{\text { no of wilting plants }}{\text { total number of plant }} \times 100$ were recorded to show percentage of root rots fungi. A representative fresh plant samples (about 150 grams) from every tray were taken at harvest, oven-dried at $70^{\circ} \mathrm{C}$ for 48 hours, and weighed to compute the moisture content.

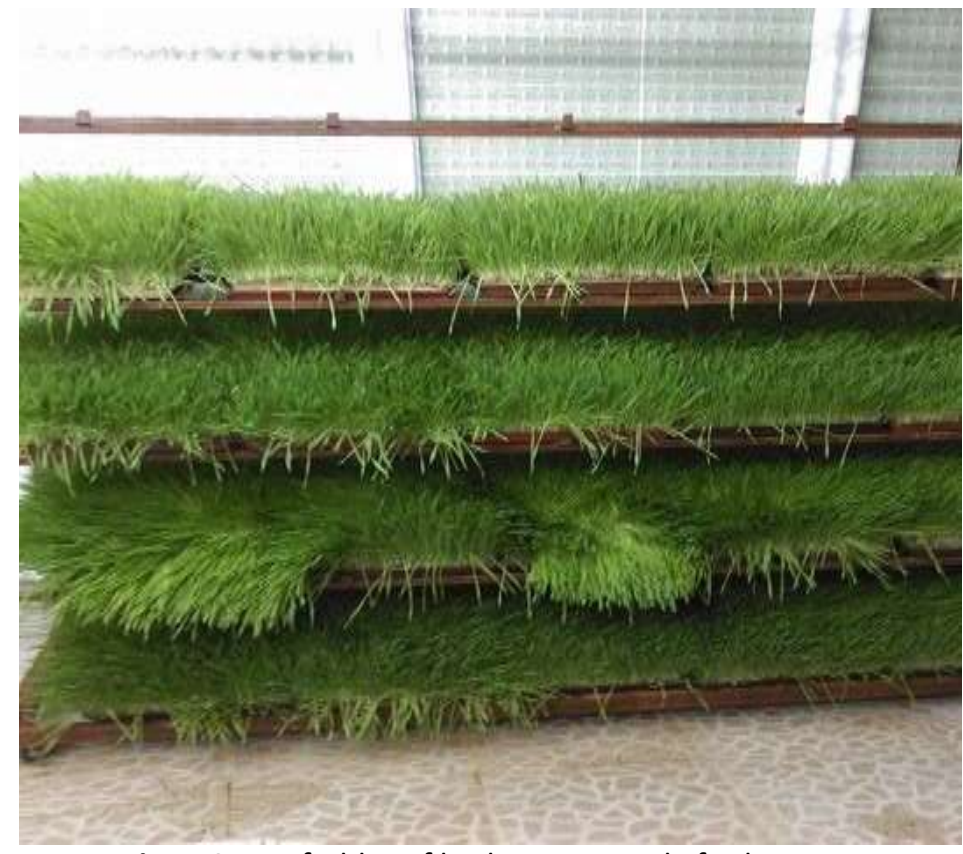

Fig 4: Green fodder of barley crop ready for harvest.

\subsection{EXPERIMENTAL DESIGN AND STATISTICAL ANALYSIS.}

Completely randomized design was used with three replicates. Data were statistically analyzed using T-test in groups using MSTATC program. Means separation were tested by LSD $(P \leq 0.05)$. 


\section{RESULTS}

\subsection{ANTIMICROBIAL ACTIVITY:}

In the present study, the antifungal activity of Azolla give higher inhibition zone more than methanolic extract. Data in table (1\& 2) and Fig (5) indicate that methanolic extract of Azolla showed inhibitory action against tested isolates, where inhibition zone diameters were, 16.58, $11.42,11.0 \mathrm{~mm}$ in case of Fusarium oxysporum, Penicillium expansum, Aspergillus niger and candida albicans respectively, but aqueous extract give inhibition zone were 18.15, 14.13, 12.0 \& $13.0 \mathrm{~mm}$ respectively. The bacterial isolate pseudomonas areuginosa was sensitive to Azolla aqueous extract, the inhibition zone was $13.0 \mathrm{~mm}$ and $10.0 \mathrm{~mm}$ by methanolic exract, staphyllococcus aurous have no inhibition zone.

Table (1) The effect of Azolla extracts on growth of tested fungi

\begin{tabular}{|c|c|c|c|c|c|c|c|c|}
\hline \multirow{3}{*}{$\begin{array}{l}\text { concentration } \\
\mathrm{mg} / \mathrm{ml}\end{array}$} & \multicolumn{8}{|c|}{ Inhibition zone (mm) } \\
\hline & \multicolumn{2}{|c|}{ F. oxysporum } & \multicolumn{2}{|c|}{ Pen.expansum } & \multicolumn{2}{|c|}{ Aspergillum niger } & \multicolumn{2}{|c|}{ Candida albinos } \\
\hline & $\begin{array}{l}\text { Cold } \\
\text { water }\end{array}$ & methanol & $\begin{array}{l}\text { Cold } \\
\text { water }\end{array}$ & methanol & $\begin{array}{l}\text { Cold } \\
\text { water }\end{array}$ & methanol & $\begin{array}{l}\text { Cold } \\
\text { water }\end{array}$ & methanol \\
\hline 60 & 18.15 & 16.58 & 14.13 & 11.42 & 14.0 & 11.0 & 13.0 & 11.0 \\
\hline
\end{tabular}

Table (3) The effect of Azolla extracts on growth of tested bacteria

\begin{tabular}{|c|c|c|}
\hline \multirow{3}{*}{ concentration $\mathrm{mg} / \mathrm{ml}$} & \multicolumn{2}{|l|}{ Inhibition zone (mm) } \\
\hline & pseudomonas areuginosa & staphyllococcus aurous \\
\hline & Cold water & Cold water \\
\hline
\end{tabular}

60

$13.0 \quad 10.0$

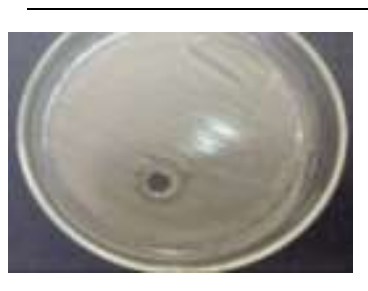

pseudomonas. aeruginosa

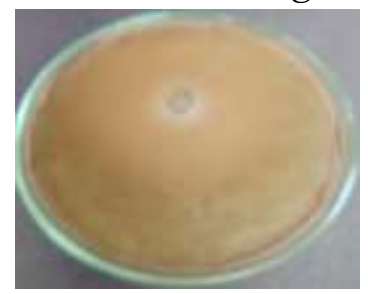

Aspergillus niger

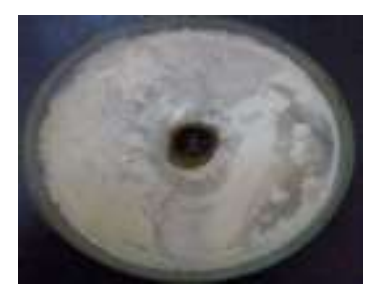

Pen.expansum Control ( DMSO)

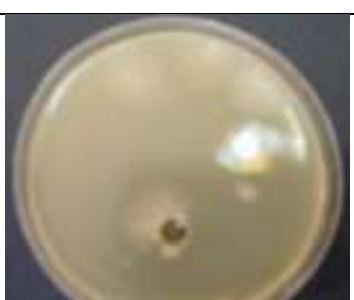

Staphylococcus aureus

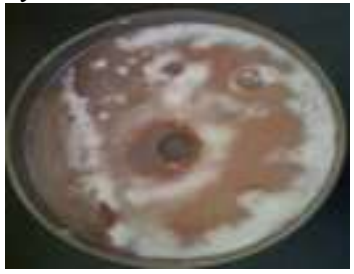

Fusarium oxysporum Control ( DSMO)

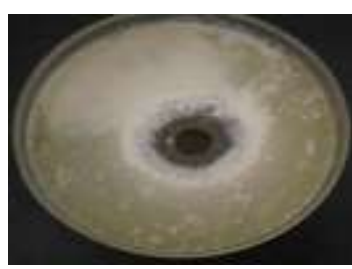

Pen.expansum + Azolla extract.

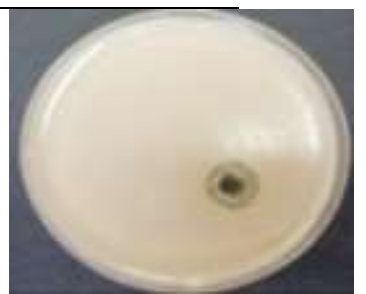

Candida albicans

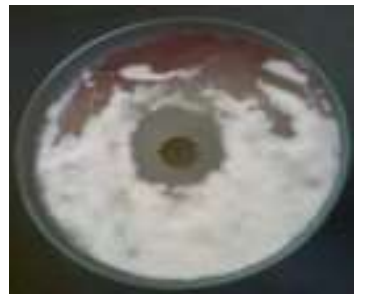

Fusarium oxysporum + Azolla extract.

Fig (5): The effect of Azolla extracts on growth of tested fungi and bacteria 


\subsection{HPLC ANALYSIS:}

The chemical composition of Azolla extract was cairied out using Hplc analysis in central labes, National Research Center, Egypt. Table (3) and Fig (6\&7) showed the extract of Azolla contain phenolic compounds such as p-hydroxybenzoic acid and flavonoids compounds such as caffeic acid.

Table (3): HPLC analysis of Azolla extract

\begin{tabular}{|c|c|}
\hline Compound & Concentration (ug/g) \\
\hline Gallic acid & ND \\
\hline Protocatechuic acid & 80.06 \\
\hline P-hydroxybenzoic acid & 48.60 \\
\hline Gentisic acid & ND \\
\hline Cateachin & 404.06 \\
\hline Cholorgenic acid & ND \\
\hline Caffeic acid & 277.27 \\
\hline Syringic acid & 510.41 \\
\hline Vanillic acid & 28.69 \\
\hline Ferulic acid & 279.23 \\
\hline Sinapic acid & 108.43 \\
\hline P-coumaric acid & ND \\
\hline Rutin & ND \\
\hline Apigenin-7-glucoside & 590.51 \\
\hline Rosmarinic acid & 5553.41 \\
\hline Cinnamic acid & ND \\
\hline Qurecetin & ND \\
\hline Apigenin & ND \\
\hline Daempferol & ND \\
\hline Chrysin & ND \\
\hline
\end{tabular}


Fig (6). Chromatogram of HPLC analysis of Azolla extract (standard)

Fig (7). Chromatogram of HPLC analysis of Azolla extract (sample)

\subsection{ULTRASTRUCTURE STUDIES:}

The ultrastructure studies showing the effect of Azolla - anabaena extracts on Fusarum oxysporum cell Fig (8).

Transmission electron micrographs showing the effect of plant extract of Azolla on Fusarium oxysporum. 
A: Fusarium oxysporum hypha grown on medium lacking plant extract of Azolla. A cell of Fusarium oxysporum surrounded by a thin wall (W) and the cytoplasm (Cy) contains numerous organelles such as mitochondria (M). Scale bar $=0.5 \mu \mathrm{m}$ (cited from Baka et al., 2002).

B, C and D: Fusarium oxysporum hypha grown on medium containing plant extract of Azolla at concentration of $0.4 \%$. Fusarium oxysporum cell show a distorted wall (w), disintegration of cytoplasm (Cy). Note large lipid bodies (L), vacuoles (v) and not recognized plasma membrane. Scale bar $=0.5 \mu \mathrm{m}$.

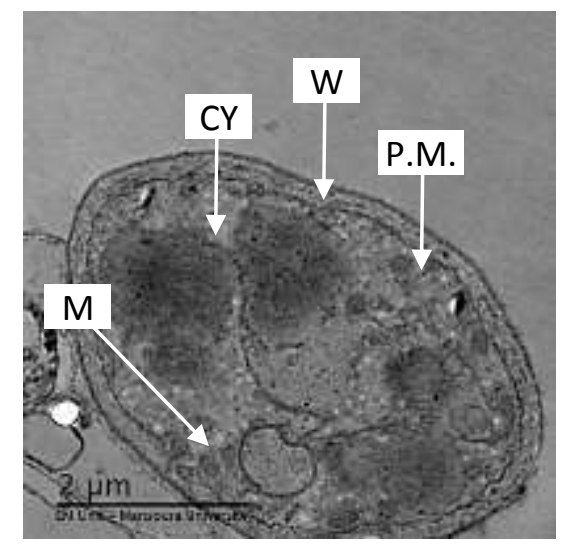

(A) Control

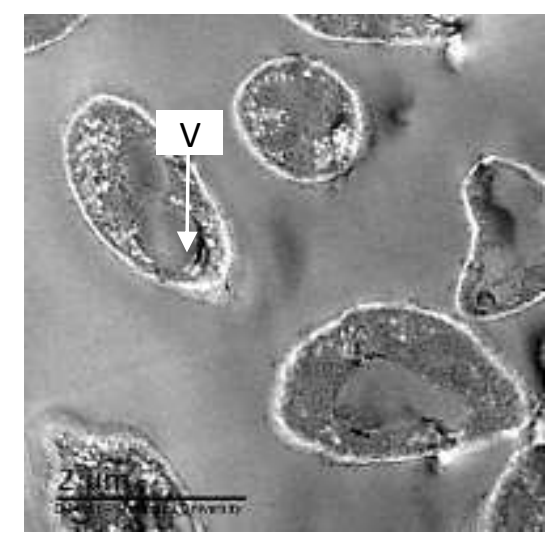

(C) Treated with Azolla extract

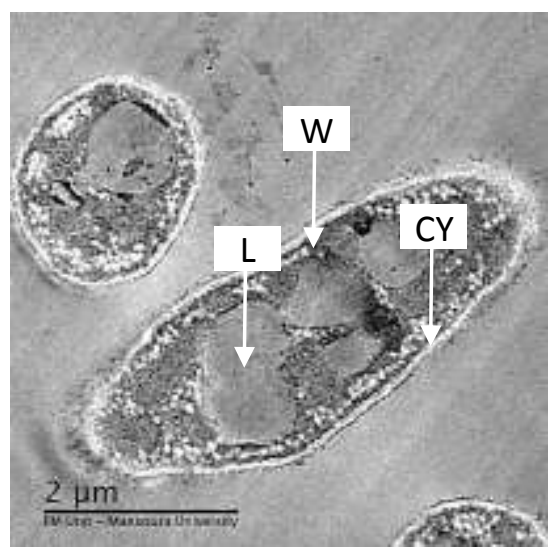

(B) Treated with Azolla extract

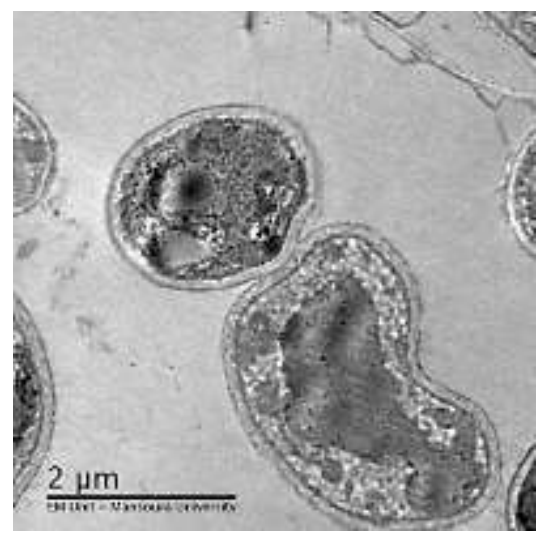

(D) Treated with Azolla extract

Fig (8): Transmission electron micrographs showing the effect of plant extract of Azolla on Fusarium oxysporum. (A) Control (B), (C) and (D) Treated with Azolla extract

The results of present study showed vegetative growth parameters and green forage production of barley after 8 days from planting (Table 4, 5, 6, 7 \& Fig. 9)

Barley seedlings treated with Azolla were significantly higher $(24 \mathrm{~cm})$ than those of without Azolla treatment $(18 \mathrm{~cm})$. According to leaves color, seedling treated with Azolla had dark green color leaves.

Table 4: Response of barley growth parameters to Azolla addition under hydroponic system over replicates.

\begin{tabular}{lll|} 
Parameters & Plant height $(\mathrm{cm})$ & Leaf color \\
Control & $18 \mathrm{~b}$ & Green \\
Treated & $24 \mathrm{a}$ & Dark green \\
\hline
\end{tabular}


T-test in groups and LSD at $\mathrm{p}=0.05$ level of significance.

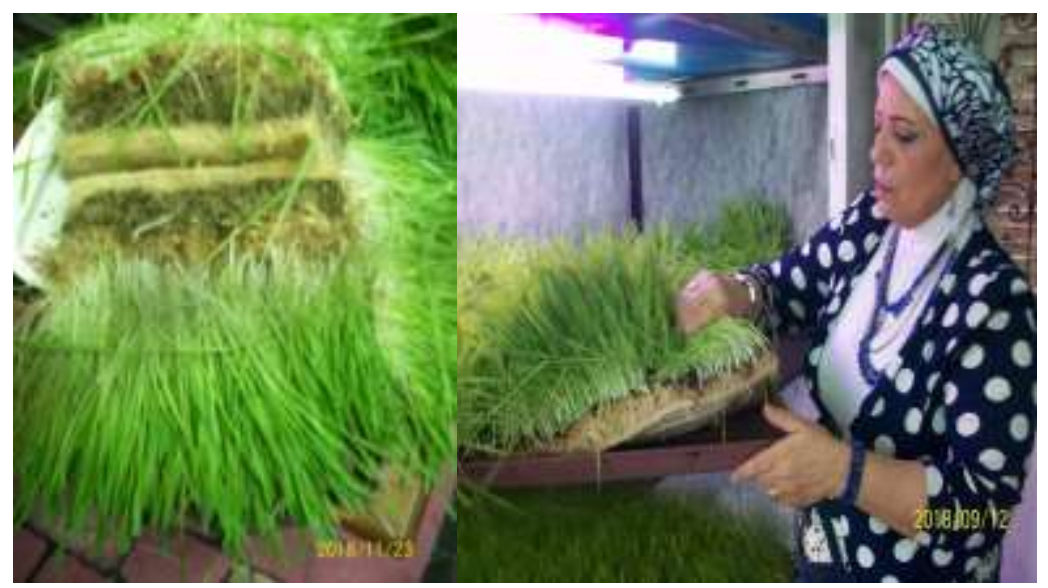

Fig 9: Green forage yield of barley with low surface layer of Azolla

. The results in Table 5 revealed that the fresh weight of barley fodder per tray in case of plants treated with Azolla were higher $(11.8 \mathrm{~kg} /$ tray) than those of plants without Azolla $(7.2$ $\mathrm{kg} /$ tray).

Table 5: Response of barley fresh and dry weight (kg/tray) to Azolla addition under hydroponic system over replicates.

\begin{tabular}{lll} 
Parameters & Fresh Weight $(\mathrm{kg} /$ tray $)$ & Dry Weight $(\mathrm{kg} /$ tray $)$ \\
Control & $7.2 \mathrm{bc}$ & $1.5 \mathrm{~b}$ \\
Treated & $11.8 \mathrm{a}$ & $2.9 \mathrm{a}$ \\
\hline
\end{tabular}

T-test in groups and LSD at $\mathrm{p}=0.05$ level of significance.

The results in Table 6 revealed the percentages of N, P, K and protein content under treated and untreated Azolla trays. Adding low surface Azolla, gave significantly higher N, P, K and protein content than untreated trays $(0.98,0.82,0.70,28.7 \%$, respectively) than those without Azolla $(0.46,0.11,0.29,20.5 \%$, respectively).

Table 6: Response of barley chemical composition to Azolla addition under hydroponic system over replicates.

\begin{tabular}{lllll} 
Parameters & $\mathrm{N} \%$ & $\mathrm{P} \%$ & $\mathrm{~K} \%$ & Protein content \% \\
Control & $0.46 \mathrm{~b}$ & $0.11 \mathrm{~b}$ & $0.29 \mathrm{~b}$ & $20.5 \mathrm{~b}$ \\
Treated & $0.98 \mathrm{a}$ & $0.82 \mathrm{a}$ & $0.70 \mathrm{a}$ & $28.7 \mathrm{a}$ \\
\hline
\end{tabular}

T-test in groups and LSD at $p=0.05$ level of significance.

Results in Table 7 showed disease incidence for treated plants with Azolla, which gave 0.0 $\%$ as compared with plants without Azolla (30\%) (Fig. 10).

Table 7: Response of barley disease incidence to Azolla addition under hydroponic system over replicates.

\begin{tabular}{llll} 
Parameters & Total No. plants & No. Infected plants & disease incidence \% \\
Control & 10.0 & $2.6 \mathrm{a}$ & $26.0 \mathrm{a}$ \\
Treated & 10.0 & $0.0 \mathrm{~d}$ & $0.0 \mathrm{~b}$ \\
\hline
\end{tabular}

T-test in groups and LSD at $p=0.05$ level of significance. 

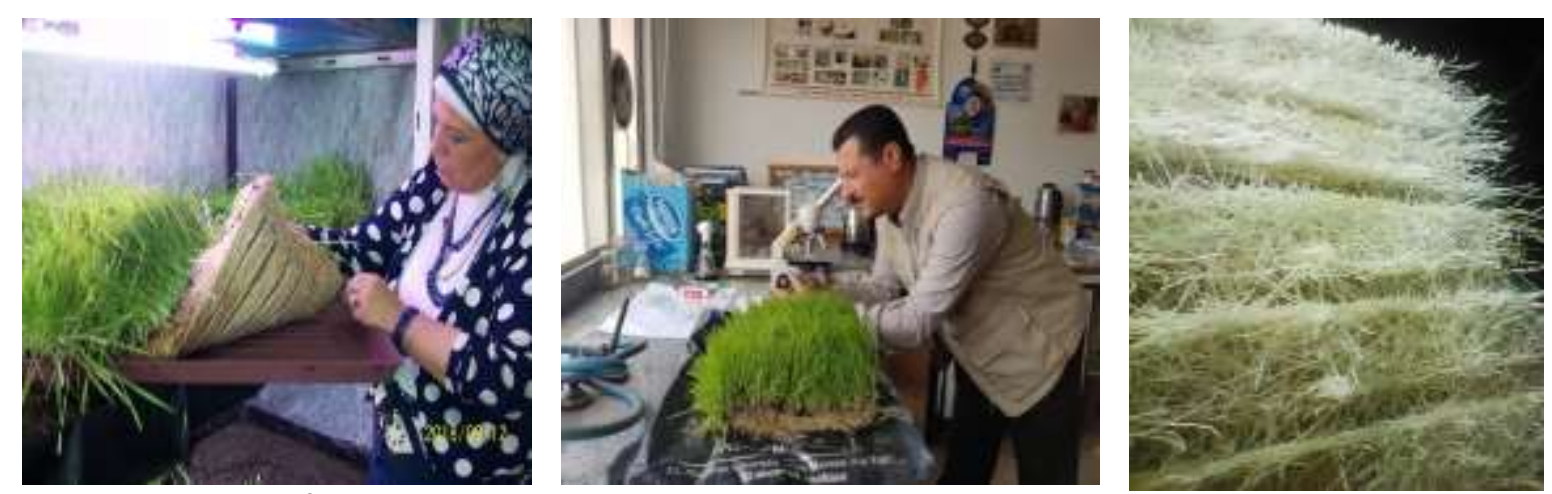

Fig. 10: Fodder barley free from root rots fungi with Azolla low surface

\section{DISCUSSION}

The results show that An.Azolla extracts had important role to inhibition of fungi also can produce active compounds like (Phenols, Flavonoids, Alkaloids, Terpens, Glycosides, Saponins) in natural aquatic ecology because the cold and hot water extracts show highly inhibition zone for Fus.oxysporum and Pen.expansum (Rossana, et al., 2006). The Anabaena algae secrete active compounds to inhibition Fus.oxysporum and Pen.expansum because these extract maybe influenced with enzyme activity of these fungi and caused inhibition (Hellio, et al., 2001).

These fungi show high sensitive to these extracts specially for cold and hot water extracts this maybe because the methanol lead to reduce activity of some active compounds which present by measured the inhibition zone and inhibition percentage, phenolic compounds in these extracts can be used as antibiotics (Abd El-Aty, et al., 2014).

The mechanism of inhibition for these extracts was facultative for active function in fungi without any side effects (Salvador, et al., 2007) and inhibition of Fus.oxysporum and Pen.expansum may be caused by effect on Mycotoxins or on spores functions or by effect on cell wall that lead to inhibition fungal cell or by influence with cell permeability (Gupta, et al., 2001) or effect on Fus.oxysporum and Pen.expansum fatty acids by decreased of saturated and unsaturated fatty acids because these extract contain mixture of active compounds leads to inhibition of fungi(Persson, et al., 2011).

An.Azolla extracts may be acts in three mechanisms on these two type of fungi, the first one these extracts effect on ergosterol(azoles) (Sheehan, et al., 1999). The second mechanism was effect to inhibition of polyenes that contract with enzymes inside cell and the third mechanism was mainly effect on enzymes that made fungal cell wall and inhibition of cell membrane fatty acids synthesis then all of these lead to inhibition these fungi (Nozawa \& Morita, 1989) .

The results of this study showed using Azolla in cultivation the barley green fodder leads to plant height were higher $24 \mathrm{~cm}$ and also the protein content of barley were very high percentage $28.7 \%$, However the fresh weight also high $11.8 \mathrm{~kg} /$ per tray because Azolla have high nutrient content. The ability of nitrogen fixation of Azolla is due to the presence of the symbiotic cyanobacterium Anabaena that occurs in the dorsal leaf cavities of the fronds (Peters and Meeks, 1989). The symbiont is able to meet the entire nitrogen requirement of the association. Calvin cycle operates in both the partners and the primary end product of photosynthesis is sucrose (Van Hove, 1989). A strong interaction exists between nitrogen fixation and the photosynthesis and the source of ATP and NADPH is photosynthesis. The capacity of Azolla to fix nitrogen in the field has been estimated to be $1.1 \mathrm{~kg} \mathrm{~N} \mathrm{ha}^{-1}$ day $^{-1}$ (Lumpkin and Plucknett, 1980). 
Because of the high nutrient content Azolla can be used as fodder for cattle and fish as well as poultry feed. It has Proteins, Vitamins, Calcium, Phosphorus, Iron, Copper, Magnesium, Beta carotene and Amino acids. It is observed that aquatic plant species especially Azolla offer a great potential as a source of protein for animals due to ease of cultivation, productivity and nutritive value (Prabha and Kumar, 2010). Poultry fed on Azolla show significant increase in the body weights and consequently have resulted in an increase in the net return (Rai $\boldsymbol{e t}$ al., 2012).

Seed soaking leads to the activation of enzymes and solubilisation and digestion of starch stored in the endosperm to simple sugars of the starch stored in the endosperm to simple sugars. This provides substrate for the young developing plant for metabolic activities. These substrates are respired to produce energy, giving off carbon dioxide and water. This loss of carbon dioxide leads to a loss in dry matter. These results were in accordance with those of (Morgan et al., 1992), who reported a significant difference in wet weight (WW) and dry weight (DW) of the hydroponic fodder. The height of barley sprouts ranged from $10 \mathrm{~cm}$ for Giza 127 to about $6.2 \mathrm{~cm}$ obtained by Giza 123. Al-Hashmi, (2008) obtained similar values regarding to the sprouts height of hydroponic barley. However, the average sprout heights of barely cultivars showed significant differences among them. Fresh sprout weight: seeds weight ratio of different cultivars illustrated in the results indicated that the highest significantly value of fresh sprout: seeds weight ratio (6.7) was recorded by Giza 127 compared to the other five cultivars. The fresh sprout weight: seeds weight ratio ranged from 6.7 to $4.4(\mathrm{Kg} / \mathrm{Kg})$. Similar results were obtained by Al-Hashmi, (2008) and Al-Karaki, (2010) they reported that the ratio reached up to 8 times in barley sprouts produced via intensive hydroponic system but under full control system.

The crude protein obtained in this study was comparable with those reported by (Al-Ajmi et al, 2009). who found about 14 percent of crude protein in hydroponically barley green fodder. (Morgan et al 1992). reported that crude protein content was increased from 10.8 at day 4 to 14.9 percent at day 8 in hydroponically barley fodder that were in accordance with our findings. (Sneath and McIntosh, 2003) evaluated the composition of sprouted barley and reported that the crude protein ranged from 11.38 to 24 percent. However, protein content may be influenced as a result of the nitrogen supplementation and other nutrients changes in sprouting grains. (Morgan et al., 199) and (Peer and Leeson, 1985) reported that protein content of green fodder is similar to barley grain, where the crude protein was higher in the green barley because of the relative decrease of other components.

Naik et al. (2015) estimated that sprouts are rich source of anti-oxidants in the form of bcarotene, vitamin-C, E and related trace minerals such as Se and $\mathrm{Zn}$. As sprouted grains (hydroponics fodder) are rich in enzymes and enzyme-rich feeds are generally alkaline in nature, therefore, feeding of the hydroponics fodder improves the animals' productivity by developing a stronger immune system due to neutralization of the acidic conditions.

\section{CONCLUSIONS}

From results of this study, it can be concluded that the barley crops showed better fodder production by using Azolla under hydroponic conditions. And free from root rot fungi. However, barley crop is considered the best choice that can be used for production of hydroponic green fodder. 


\section{REFERENCES}

- Andersen, R. A. and Kawachi, M. 2005. Traditional Microalgae Isolation Techniques In: Andersen, R.A. [Ed.] Algal Culturing Techniques. Academic Press, San Diego.578.

- Al-Hashmi, M. M., 2008. Hydroponic green fodder production in the Arabian Gulf Region. MSc. Thesis,Faculty of Graduate Studies, Arabian Gulf University, Bahrain.

- Al-Karaki, G.N., and N. Al-Momani. 2011. Evaluation of some barley cultivars for green fodder production and water use efficiency under hydroponic conditions. Jordan Journal of Agricultural Sciences 7(3): 448-456.

- Abd El-Aty, M; Mohamed, A; Samhan , A. 2014. In vitro antioxidant and antibacterial activities of two fresh water Cyanobacterial species, Oscillatoriaagardhii and Anabaena sphaerica. Journal of Applied Pharmaceutical Science, 4 (7): 069-075.

- Blahova, L;Adamovsky, O; Kubala, L; Svihalkovd, L; Zounkova, R; and Blaha, L. 2013. The isolation and characterization of lipopolysaccharides from Microcystaeruginosa, aprominent toxic water bloom forming cyanobacteria Toxicon 76:187-196.

- Desikaghary, F.R. 1959. Cyanophyta, London, Acad. Press.

- Ghazi N. Al-Karaki1 and M. Al-Hashimi 2012. Green Fodder Production and Water Use Efficiency of Some Forage Crops under Hydroponic Conditions. Volume 2012, Article ID 924672.

- Griffiths, D.J; and Saker, M.L. 2003. The Palm Island mystery disease 20 years on: a review of research on the cyanotoxin cylindrospermopsin. Environ Toxicol, 18(2): p. 78-93.

- Gupta, C. P.; Dubey, R. C.; Kang, S. C. and Maheshwari, D. K. 2001. Antibiosismediatednecrotrophic effect of Pseudomonas GRC2 against two plant pathogens. Curr Sci. 81(1): 91-94.

- Hellio C, De La Broise, D., Dufossé, L., Le Gal, Y. \&Bourgougnon , N . 2001. Inhibition of marine bacteria byextracts of macroalgae: Potential use for environmentallyfriendly antifouling paints. Marine Environmental Research, 52: 231-247.

- Jawad, A.L.M. 1982. Interactions Between Cyanobacteria and Other Microorganisms. Ph.D Thesis, Liverpool University, 123-125.

- Lumpkin, T. A.; Plucknett, D. L. 1980. Azolla: Botany, Physiology and use as a green manure Econ Bot $34: 111-153$.

- Moe, C.L. 1997. Waterborne transmission of infectious agents, in Manual of environmental microbiology, C.J. Hurst, G.R. Knudsen, M.J. McInerney, L.D. Stetzenbach and M.V. Walter, Editors. American Society for Microbiology: Washington, 136-52.

- Morgan, J., R. R. Hunter ; R. O'Haire, 1992. Limiting Factors in Hydroponic Barley Grass Production.Proceedings of the 8th International Congress on Soilless Culture, Hunter's Rest, 2-9 October 1992, 241-261.

- Nozawa Y, Morita T. 1989. Molecular mechanisms of antifungal agents associated with membrane ergosterol. Dysfunction of membrane ergosterol and inhibition of ergosterol biosynthesis. In: Iwata $\mathrm{K}$, VandenBossche $\mathrm{H}$, editors. In vitro and in vivo evaluation of antifungal agents. Amsterdam, The Netherlands: Elsevier Science Publishers, B. V.; p. 111.

- Persson F, R Svensson, GM Nylund, NJ Fredriksson, H Pavia \& M Hermansson. 2011. Ecological role of asecondary metabolite for a colonizing bacterial community.Biofouling 27: 579-588. 
- Peters, G. A. ; Meeks, J. C. 1989. The Azolla-Anabaena symbiosis: basic biology. Ann Rev Plant Physiol Plant Mol Biol 40 193-210

- Prabha, B. J. ; Kumar, K. 2010. Dried Azolla as a nutritionally rich cost effective and immuno-modulatory feed supplement for broilers Asian J Animal Sci 5(1) 20-22

- Priya-Gopinath, T. and Ajit Kumar, K. G. 2015. Micro algal Diversity of the OF THE Fresh Water lake In Thiruvananthapuram district, Kerala. International Journal of Plant, Animal and Environmental Sciences, Vol.5, No.1, pp.

- Rai, R. B.; Dhama, K.; Damodaran, T., Hamid, A.; Rai, S.; Singh, B.; Bhatt, P. 2012. Evaluation of Azolla (Azolla pinnata) as a poultry feed and its role in poverty alleviation among landless people in northern plains of IndiaVet Practitioner 13(2) 250-254

- Rippka, R.; Deruelles, J.; Waterbury, J.B.; Herdman, M. and Stanier, R.Y. 1979. Generic assignments, strain histories and properties of pure cultures of cyanobacteria. Journal of General Microbiology,.111(1): 1-61.

- Rossana, A.C.; Valdirene, M.G.; Ana, F.U.; Candvania, M. 2006. Effect of proteins from the red seaweed Hypneamusciformis (Wulfen) Lamouroux on the growth of human pathogen yeasts. Brazilian of Biology and Technol., 49:915-921.

- Salman, J.M; and Abdul-Adel, E. 2015. Potential use of cyanophyta species Oscillatorialimneticain bioremediation of organophosphorus herbicide glyphosate. Mesop. Environ. J, 1(4): 15-26.

- Salvador, N., Gómez, G. A., Lavelli, L. and Ribera, M. A. 2007. Antimicrobial activity of Iberian macroalgae. Scientia Marina 71: 101-113.

- Sheehan D J, Hitchcock C A, Sibley C M. 1999. Current and emerging azole antifungal agents. ClinMicrobiol Rev. 12:40-79.

- Shoker R. M. H. and Jawad, A. M. 2013. Evaluation of Isolated Compounds Activity from Convolvulus Arvensis Against Algae. Iraqi Journal of Science, Vol.54,No.1,pp.62-71.

- Sivonen ,K; and Jones, G. 1999. Cyanobacterial toxins. In: Chorus, I. and J. Bartram(Eds.),toxic cyanobacteria in water :Aguide to their public health, consequences, monitoring and management, London: WHO:41-111.

- Tredici, M.R. 2004. Mass production of microalgae: photobioreactors. In: Richmond A.[Eds.] Handbook of Microalgal Culture: Biotechnology and Applied Phycology. Oxford: Blackwell Science.

- Van Hove, C. 1989. Azolla and its multiple uses with emphasis on Africa, Food and Agricultural Organization, Rome

- WHO, 2003. Guidelines for safe recreational water environments - Volume 1: coastal and fresh waters. World Health Organization: Geneva.

- Yousif, D.Y.M. 2014. Activity of some Macro-algae Extracts Against phytopathognic Fungi, Ph.D. thesis, Coll. Of science, University of Baghdad, Iraq. Reynolds, E.S., 1963. The use of lead citrate at high $\mathrm{pH}$ as an electron-opaque stain in electron microscopy. J. Cell Biol. 17, 208-212. 